\title{
A regulatory take on cannabis and cannabinoids for medicinal use in the European Union
}

\author{
Metoda Lipnik-Štangelj ${ }^{1}$ and Barbara Razinger ${ }^{2}$ \\ ${ }^{1}$ University of Ljubljana, Faculty of Medicine, Department of Pharmacology and Experimental Toxicology, Ljubljana, Slovenia \\ 2 Agency for Medicinal Products and Medical Devices of the Republic of Slovenia, Ljubljana, Slovenia
}

[Received in June 2019; Similarity Check in June 2019; Accepted in February 2020]

\begin{abstract}
The discovery of the endocannabinoid system has raised public interest in the medicinal use of cannabis, phytocannabinoids, and synthetic cannabinoids, which has always been closely regulated due to their psychotropic effects and potential abuse. The review takes a quick look at the current legal framework in the European Union, which regulates cannabis use and cultivation for medicinal purposes in line with the United Nations Conventions on the production, trade, and use of cannabis, phytocannabinoids, and synthetic cannabinoids. And while the EU legislation precisely defines requirements and marketing authorisation procedures for medicinal products for all EU member states, there is no common regulatory framework for magistral and officinal preparations containing cannabinoids, as they are exempt from marketing authorisation. Instead, their regulation is left to each member state, and it is quite uneven at this point, mainly due to cultural and historical differences between the countries, leading to different access to non-authorised medicinal products. Therefore, to meet great public interest, harmonised approaches on cannabinoid-containing products without marketing authorisation would be welcome to level the playing field in the EU.
\end{abstract}

KEY WORDS: cannabis cultivation; legislation; magistral preparations; officinal preparations; phytocannabinoids; synthetic cannabinoids

Different species of the genus Cannabis make part of human life since ancient times. Industrial cannabis (hemp) and medicinal cannabis (marijuana) are genetically distinct forms of the plant Cannabis sativa L., the major difference between them being the content of psychoactive compounds. While hemp contains no more than $0.2 \%$ of psychoactive $\Delta$ 9-tetrahydrocannabinol (THC) weight per weight (w/w), medicinal cannabis contains more (1). Hemp is usually cultivated for the production of a wide range of industrial products like fibres in textiles, paper, and construction materials or seeds in foodstuffs, whereas marijuana has a long history of cultivation for psychotropic (religious or medicinal) use (2, 3).

At the beginning of the twentieth century, the medicinal use of cannabis had largely declined (1), but the discovery of the endocannabinoid system has recently revived interest in the potential therapeutic use of various cannabinoid derivatives (4). The problem, however, is the abuse of cannabis over its psychotropic effects. As it may pose a serious risk to public health, it has long been regulated by legislation, and cannabis and phytocannabinoid-containing products are the most commonly used illicit drugs in the world. However, laws regulating the safe use of

Corresponding author: Metoda Lipnik-Štangelj, University of Ljubljana, Faculty of Medicine, Department of Pharmacology and Experimental toxicology, Korytkova 2, 1000 Ljubljana, Slovenia

E-mail: metoda.lipnik-stangelj@mf.uni-lj.si phytocannabinoids differ greatly between countries, reflecting a variety of historical and cultural backgrounds $(3,4)$. The aim of this article is to review current legislation, focusing on the use of medicines and cannabis cultivation in the European Union (EU) and to show in what areas the legislation of medicinal products containing cannabinoids varies across EU countries, leading to different accessibility to these products.

\section{CANNABIS AND CANNABINOIDS IN MEDICINE}

Ever since the nineteenth century approval of the use of cannabis tincture to relieve pain and nausea in Britain (5), most countries allow medicinal use of cannabinoids as one of the legal treatment options (1). By definition, cannabinoids are substances that bind the cannabinoid receptors of the body and trigger similar effects to those evoked by the plant $C$. sativa (3). They are most often classified according to their origin and structure.

Endocannabinoids are endogenous neurotransmitters that bind to cannabinoid $\mathrm{CB}_{1}$ and $\mathrm{CB}_{2}$ receptors in the mammalian central and peripheral nervous system. In the past 15 years, they have been shown to share metabolic pathways and molecular targets with a number of lipid mediators. They make a complex system, described as endocannabidiome, which regulates several physiological 
processes. These include pain, cognition, motor activity, appetite, nausea, vomiting, and some endocrine, inflammatory, and immune reactions. Endocannabidiome receptors and metabolic enzyme targets can therefore be useful in the treatment of various symptoms and diseases such as pain, nausea, depression, anxiety, and neurological disorders like multiple sclerosis and epilepsy (6-8).

Phytocannabinoids are the first known psychoactive cannabinoids. They are components of $C$. sativa and some other plant species. So far, there are over 100 known phytocannabinoids, some of which are present in plants in very low concentrations. The most abundant phytocannabinoid, readily extracted from $C$. sativa is the psychoactive $\Delta 9$-tetrahydrocannabinol (THC). Other common phytocannabinoids are not psychoactive and include cannabidiol (CBD), cannabigerol (CBG), and cannabichromene (CBC) (9).

Syntethic cannabinoids have been used in medicine since the second half of the $20^{\text {th }}$ century. Historically, they are based on the structure of phytocannabinoids, but this is not true of newer synthetic compounds. Currently, there are two products containing synthetic cannabinoids that have been approved for medicinal use in some EU member states: dronabinol, which is synthetic THC, and nabilone, which is a synthetic analogue to THC (Table 1). Current drug research is mainly based on synthetic cannabinoids. Besides medicinal use, several CB1 receptor-selective agonists have been developed as psychoactive ingredients in products for recreational use. Since little is known about their effects in humans, and since some of them cause more distress and panic than phytocannabinoids, they represent a significant health risk (10-13).

\section{LEGISLATION OF CANNABINOID-BASED MEDICINAL PRODUCTS}

Legislation on cannabis issues is nearly 100 years old. When cannabis came under international control under the revised International Opium Convention of 1925, it was referred to as 'Indian hemp'. The Convention referred only to the dried tops of the pistillate plant, particularly rich in 'pharmaceutically strong active resin' and banned the export of cannabis resin to countries that prohibited its use and established domestic control, such as penalties for unauthorised possession of cannabis extract and tincture. The Convention also proposed that any breaches of national laws should be penalised (14).

Three United Nations (UN) conventions, signed by all EU member states, outline the basic framework for controlling the production, trade, and possession of over 240 psychoactive substances, many of which have therapeutic potential. These conventions classify narcotic drugs and psychotropic substances, including cannabis, according to their danger to health, risk of abuse, and therapeutic value.
The first, 1961 Single Convention on Narcotic Drugs (15), classified narcotic drugs and seeks to combat drug abuse through concerted international measures. It proposed two forms of intervention and control with the aim to: a) limit the possession, use, trade, distribution, import, export, and production of drugs exclusively for medical and scientific purposes; and b) combat drug trafficking through international cooperation. The Convention did not differ between industrial hemp and medicinal cannabis and classified cannabis in Schedule I as a substance presenting a serious risk of abuse, whose properties give rise to dependence. Cannabis was also included in Schedule IV among the most dangerous substances due to their particularly harmful characteristics, the risks of abuse, and limited therapeutic value. This significantly limited the use of cannabis and cannabinoids for medicinal purposes, which has later raised a number of controversies (16).

The 1971 UN Convention on Psychotropic Substances (17) included new, synthetic drugs of abuse, such as synthetic cannabinoids, taking into account their abuse potential as well as their therapeutic value.

The 1988 UN Convention against Illicit Traffic in Narcotic Drugs and Psychotropic Substances (18) has established comprehensive international measures against drug trafficking, money laundering, and abuse of drug precursors. The Convention also binds member countries to prevent illicit cannabis cultivation and to eradicate cannabis plants on their territory.

These three conventions, however, do not specify that drug use should be a punishable offence. Instead, each country is free to regulate this issue. In addition, the conventions do not associate drug types with the severity of penalties and even though the schedules affect the procedures for the legal trade of the drugs, the countries are not bound to use them.

International drug control has evolved, and nowadays it does not ban cannabis or cannabis-based product use in medicine to treat specific indications. While international law provides a general regulatory framework for the cultivation and marketing of cannabis, the EU law sets the criteria for medicinal products, including those containing cannabinoids, to be authorised for marketing in the EU member states. However, magistral and officinal formulas are exempt from the EU marketing authorisation rules and are left to the care of the EU member states. This eventually leads to different access for patients to these medicinal products containing cannabinoids in the EU countries.

\section{EU AND MEMBER STATE LEGISLATION}

Cannabis and cannabinoids have their place in pharmacotherapy in the EU member states. They are mostly indicated for treating chronic pain, nausea, and vomiting due to chemotherapy or to relax muscle stiffening caused by multiple sclerosis $(7,19,20)$. They occur in various 
formulations, yet some products have a marketing authorisation for medicinal use and others do not (Figure 1) (1).

\section{Cannabinoid-containing products with marketing authorisation}

The EU legal framework for authorised medicinal products for human use has been laid down by the Directive 2001/83/EC of the European Parliament and of the Council and its amendments (21). All of the cannabinoid-based medicines that pass the centralised procedure for marketing authorisation can be marketed in all the EU member states and prescribed by physicians according to their approved indications and posology. So far, only one cannabinoidbased product with a trade name Epidyolex (containing $10 \%$ of CBD isolated from cannabis) has been approved for the treatment of intractable childhood epilepsy by the European Medicines Agency (EMA) in 2019 and received the orphan drug designation in 2014 (Table 1) $(22,23)$.

Beside the centralised EMA procedure for marketing authorisation, cannabinoid-based products can be authorised through a decentralised procedure, mutual recognition procedure, or national procedures of the member states, which limit their use to the market of the member state involved in the procedure. Having a marketing authorisation implies that the product has been tested for safety and efficacy through extensive non-clinical and clinical trials. Regulatory authorities also consider whether the product meets the required level of quality. So far, there are but a few authorised medicinal products containing nabiximols, dronabinol, or nabilone on the EU member state markets (Table 1) (22-26). Other cannabinoid-based medicines are in different stages of development but have not yet been authorised for marketing.

\section{Cannabinoid-containing products with no marketing authorisation}

According to its article 3, the Directive 2001/83/EC (21) does not apply to magistral and officinal formulas and leaves their regulation to the jurisdictions of member states, which may include a wide range of cannabinoid-containing products (1).

In most EU countries this exemption enables pharmacists to prepare magistral formulas for use in accordance with a specified medical prescription for an individual patient. It also allows the production of larger batches (officinal formulas, aka stock or standardised preparations) in accordance with national pharmacopoeia or national formularies. Although it is uncommon in the EU member states to use raw cannabis for medicinal purposes, some countries allow patients access to officinal cannabis preparations such as Croatia, Czech Republic, Denmark, Finland, Germany, Italy, Luxembourg, Netherland, Poland, and Sweden (1, 27-31). Magistral preparations are also available through special access schemes in Czech Republic, Germany, Italy, and the Netherlands and through exceptional/compassionate use programmes in Croatia, Denmark, Finland, Poland, and Sweden. These approaches enable medical approval and oversight, limit medicinal use to a specific set of medical conditions, and generally restrict the use of cannabis preparations. Their use may further be restricted by lack of health insurance coverage, as national regulatory frameworks are not always clear about how officinal and magistral preparations should work in practice. For example, officinal (standard) preparations in Estonia need approval by the Estonian State Agency of Medicines; in Finland, officinal preparations with nabiximols are allowed; in Sweden, only a small number of patients are granted permission to use cannabis preparations (1). In addition, some EU member states like Germany have pharmacopoeias and/or formularies (32) which include

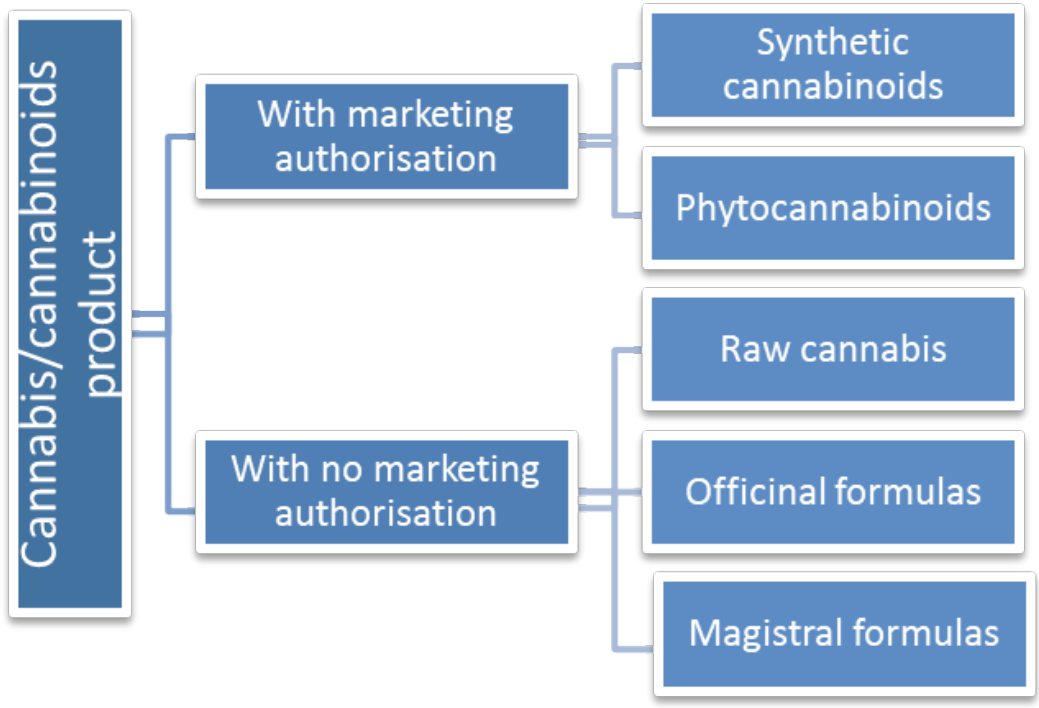

Figure 1 Different legal status of cannabinoid-based medicinal products 
Table 1 Authorised cannabis-based medicines in the EU member states in 2018

\begin{tabular}{|c|c|c|c|c|}
\hline $\begin{array}{l}\text { INN } \\
\text { Form }\end{array}$ & Description & Availability & $\begin{array}{l}\text { Indications } \\
\text { Strength of evidence }\end{array}$ & Reference \\
\hline \multirow{7}{*}{$\begin{array}{l}\text { Nabiximols } \\
\text { Sublingual } \\
\text { spray }\end{array}$} & \multirow{7}{*}{ Extract of cannabis: } & $\begin{array}{c}\text { Most EU member states } \\
\text { except: }\end{array}$ & \multirow{7}{*}{$\begin{array}{l}\text { Muscle spasm in multiple } \\
\text { sclerosis }\end{array}$} & \multirow{7}{*}{1,24} \\
\hline & & $\begin{array}{l}\text { Bulgaria } \\
\text { Cyprus }\end{array}$ & & \\
\hline & & Greece & & \\
\hline & & Hungary & & \\
\hline & & Latvia & & \\
\hline & & Romania & & \\
\hline & & Slovakia & & \\
\hline \multirow{7}{*}{ Dronabinol } & \multirow{7}{*}{ Synthetic $\Delta 9$-THC } & Croatia & \multirow{2}{*}{ AIDS related wasting } & \multirow{7}{*}{1,25} \\
\hline & & Denmark & & \\
\hline & & France & \multirow{2}{*}{ Weak; } & \\
\hline & & Ireland & & \\
\hline & & Poland & Little evidence available about & \\
\hline & & $\begin{array}{l}\text { Slovenia } \\
\text { Spain }\end{array}$ & stimulation of appetite in people & \\
\hline & & Sweden & & \\
\hline \multirow{5}{*}{ Nabilone } & \multirow{9}{*}{$\begin{array}{c}\text { Synthetic } \\
\text { cannabinoid, similar } \\
\text { to } \Delta 9-\mathrm{THC}\end{array}$} & Austria & & \multirow{9}{*}{1,26} \\
\hline & & Croatia & & \\
\hline & & Denmark & & \\
\hline & & Ireland & Nausea and vomiting associated & \\
\hline & & Germany & with cancer chemotherapy & \\
\hline Capsule & & Poland & Weak & \\
\hline & & Slovenia & weak & \\
\hline & & Spain & & \\
\hline & & United Kingdom & & \\
\hline \multirow{2}{*}{$\begin{array}{l}\text { Cannabidiol } \\
\text { Oral solution }\end{array}$} & \multirow{2}{*}{$\begin{array}{l}\text { Extract of cannabis: } \\
\text { CBD }\end{array}$} & \multirow{2}{*}{$\begin{array}{c}\text { Authorised for use in } \\
\text { all EU member states in } \\
2019 \text { asorphan medicinal } \\
\text { product }\end{array}$} & $\begin{array}{c}\text { Intractable childhood epilepsy } \\
\text { (Lennox-Gastaut syndrome or } \\
\text { Dravet syndrome) }\end{array}$ & \multirow[t]{2}{*}{22,23} \\
\hline & & & Moderate & \\
\hline
\end{tabular}

$\overline{\mathrm{INN}}$ - international nonproprietary name

monographs for the preparation of cannabis extracts, and some like Slovenia do not. This is why magistral and officinal formulas cannot be prescribed in Slovenia $(33,34)$ and can in Germany. These discrepancies could be overcome by harmonising relevant European pharmacopoeia monographs.

\section{LEGAL FRAMEWORK FOR CANNABIS CULTIVATION FOR MEDICINAL PURPOSES AND FOOD PRODUCTS}

International law does not ban the cultivation of cannabis for medicinal use. Instead, the 1961 UN Convention provides a general system of control, if a country decides to grant cannabis cultivation not intended for industrial or horticultural purposes. Each country has the exclusive right to buy the entire cannabis production on its territory (15). Cultivation and primary processing of cannabis directly influence the quality of active pharmaceutical ingredients and should therefore comply with the provisions of the UN Conventions and the WHO guidelines of good agricultural and collection practices (35) for medicinal plants. For the EU member states EMA additionally provides Guidelines on Good Agricultural and Collection Practices (GACP) (36) that include a system of quality control of medicinal plants and herbal substances from cultivation to distribution.

Cultivation of medicinal cannabis in the EU is currently allowed in Austria, Czech Republic, Italy, Germany, Greece, Malta, the Netherlands, and Portugal. All of these member states have established an authority for cannabis cultivation and defined their responsibilities as summarised in Table 2 $(1,27,37-40)$.

Hemp can also be cultivated in the EU for food, provided that it is registered in the EU's Common Catalogue of Varieties of Agricultural Plant Species (41) and that its THC content does not exceed $0.2 \% \mathrm{w} / \mathrm{w}$. Furthermore, in the Novel Food catalogue (42) the EC has listed C. sativa extracts with cannabidiol content higher than in hemp, and 
Table 2 Medicinal cannabis cultivation in the EU member states in 2018

\begin{tabular}{|c|c|c|c|}
\hline $\begin{array}{l}\text { EU member } \\
\text { state }\end{array}$ & $\begin{array}{l}\text { Responsible authority } \\
\text { for medicinal cannabis } \\
\text { cultivation }\end{array}$ & Responsibilities & Ref. \\
\hline Austria & $\begin{array}{l}\text { Austrian Agency for Health } \\
\text { and Food Safety }\end{array}$ & $\begin{array}{l}\text { It is responsible for the production of medicinal cannabis, } \\
\text { purchases cannabis and ensures its distribution and export. }\end{array}$ & 1,40 \\
\hline $\begin{array}{l}\text { Czech } \\
\text { Republic }\end{array}$ & $\begin{array}{l}\text { State Agency for Medical } \\
\text { Cannabis established } \\
\text { within the State Institute of } \\
\text { Drug Control }\end{array}$ & $\begin{array}{l}\text { It is responsible for licensing of medicinal cannabis } \\
\text { cultivation, purchases cannabis and ensures its distribution } \\
\text { and export. } \\
\text { It set rules for e-prescription, pharmacies and so forth; a } \\
\text { special registry started operating in November } 2014 \text {. }\end{array}$ & 1,40 \\
\hline Italy & Italian Ministry of Health & $\begin{array}{l}\text { It is the coordinating body for medical cannabis and has the } \\
\text { responsibility to issue permits for cultivation, production, } \\
\text { possession, and use of cannabis. It supervises the conditions } \\
\text { for the cultivation of cannabis for medical purposes and has } \\
\text { an exclusive right of redemption and resale cannabis. }\end{array}$ & 1,40 \\
\hline Germany & $\begin{array}{l}\text { Medical Cannabis Agency, } \\
\text { established within the } \\
\text { German Federal Institute } \\
\text { for Drugs and Medical } \\
\text { Devices (BfArM) }\end{array}$ & $\begin{array}{l}\text { It selects breeders who meet the required conditions; contracts } \\
\text { with them in which the obligations of the breeders are defined; } \\
\text { exercise the control over breeders who, in case of breach } \\
\text { of contractual provisions, lose the right to grow; has the } \\
\text { exclusive right to buy and sell resin cannabis. }\end{array}$ & $1,29,40$ \\
\hline Greece & $\begin{array}{l}\text { Ministry of Health, Greek } \\
\text { National Organization for } \\
\text { Medicines }\end{array}$ & $\begin{array}{l}\text { It is responsible for licencing of medicinal cannabis } \\
\text { cultivation and production (first two licences were granted to } \\
\text { private companies Bioprocann SA and Biomecann). }\end{array}$ & 38 \\
\hline Malta & Maltese Ministry of Health & $\begin{array}{l}\text { It is responsible for licensing of medicinal cannabis } \\
\text { cultivation, monitoring, purchasing, distribution, import, } \\
\text { export, and destruction of cannabis. }\end{array}$ & 37 \\
\hline Nederlands & $\begin{array}{l}\text { Office of Medicinal } \\
\text { Cannabis of the } \\
\text { Netherlands government }\end{array}$ & $\begin{array}{l}\text { It is responsible for controlling of greenhouse cultivation with } \\
\text { controlled conditions (GMP); analytical testing; packaging } \\
\text { and distribution of cannabis to authorized pharmacies. }\end{array}$ & 1,40 \\
\hline Portugal & $\begin{array}{l}\text { Instituto Nacional da } \\
\text { Farmacia e do Medicament } \\
\text { (INFARMED) }\end{array}$ & $\begin{array}{l}\text { It is responsible for licencing of medicinal cannabis } \\
\text { cultivation, manufacturing, processing and distribution. }\end{array}$ & 39 \\
\hline
\end{tabular}

them banned in food, including dietary supplements, until safety assessment is completed.

\section{CONCLUSIONS}

The growing interest in the use of cannabis and cannabinoid products forces countries to regulate cultivation and safe use of cannabis and its products for medicinal use. The basic regulatory framework is provided by the UN conventions, whereas the EU legislation covers only medicinal products that have been authorised for marketing. The regulation of cannabinoid-containing products without marketing authorisation - magistral and officinal (standardised) preparations - is left to each EU member state and is quite uneven across the EU, mainly due to cultural and historical differences between the countries. There are different approaches to this kind of regulation that cannot be easily transferred from one EU country to another, yet uneven availability of cannabinoid-containing medicinal products calls for some harmonisation of these approaches to level the playing field and avoid issues such as cross-border patient access where EU countries have different regulatory schemes.

\section{REFERENCES}

1. European Monitoring Centre for Drugs and Drug Addiction. Medical use of cannabis and cannabinoids: questions and answers for policymaking. Luxembourg: Publications Office of the European Union; 2018 [displayed 22 March 2019]. Available at http://www.emcdda.europa.eu/publications/ rapid-communications/medical-use-of-cannabis-andcannabinoids-questions-and-answers-for-policymaking_en

2. Congressional Research Service. Report R44742. Defining Hemp: A Fact Sheet [displayed 22 March 2019]. Available at https://crsreports.congress.gov

3. Zuardi AW. History of cannabis as a medicine: A review. Rev Bras Psiquiatr 2006;28:153-7. doi: 10.1590/S151644462006000200015

4. Abuhasira R, Shbiro L, Landschaft Y. Medical use of cannabis and cannabinoids containing products - Regulations in Europe and North America. Eur J Intern Med 2018;49:2-6. doi: 10.1016/j.ejim.2018.01.001

5. Grinspoon L, Bakalar J. Marihuana: The Forbidden Medicine. New Haven: Yale University Press; 1997.

6. Di Marzo V. New approaches and challenges to targeting the endocannabinoid system. Nat Rev Drug Discov 2018; 17:62339. doi: $10.1038 / \mathrm{nrd} .2018 .115$

7. Ferjan I, Kržan M, Lipnik-Štangelj M, Žiberna L, Stanovnik L, Černe K. Farmakologija kanabinoidov. Zdrav Vestn 
2015;84:456-71 [displayed 22 March 2019]. Available at https://www.dlib.si/stream/URN:NBN:SI:DOCKYQQTGWH/08a52892-59b7-40b8-9da3-6a9b38f289d8/ PDF

8. Fine PG, Rosenfeld MJ. The endocannabinoid system, cannabinoids, and pain. Rambam Maimonides Med J 2013;4(4):e0022. doi: 10.5041/RMMJ.10129

9. Andre CM, Hausman JF, Guerriero G. Cannabis sativa: The plant of the thousand and one molecules. Front Plant Sci 2016;7:19. doi: 10.3389/fpls.2016.00019

10. Panlilio LV, Goldberg SR, Justinova Z. Cannabinoid abuse and addiction: Clinical and preclinical findings. Clin Pharmacol Ther 2015;97:616-27. doi: 10.1002/cpt.118

11. Mulalić E, Sollner Dolenc M. Synthetic cannabinoids. In: Drev A, editor. Report on the drug situation 2015 of the Republic of Slovenia. Ljubljana: Inštitut za varovanje zdravja; 2015. p. 21-2 [displayed 22 March 2019]. Available at http://www.nijz.si/sites/www.nijz.si/files/publikacijedatoteke/nr_2015_f.pdf

12. Sutlović D, Prkačin I, Vaiano F, Bertol E, Veršić Bratinčević M, Definis-Gojanović M. A case of synthetic cannabinoid poisoning in Croatia. Arh Hig Rada Toksikol 2018;69:18690. doi: 10.2478/aiht-2018-69-3100

13. Vučinić S, Kilibarda V, Đorđević S, Đorđević D, Perković Vukčević N, Vuković-Ercegović G, Antonijević B, Curčić M, Antonijević E, Brajković G. Clinical and analytical experience of the National Poison Control Centre with synthetic cannabinoids. Arh Hig Rada Toksikol 2018;69:17885. doi: 10.2478/aiht-2018-69-3096

14. European Monitoring Centre for Drugs and Drug Addiction. Cannabis legislation in Europe: an overview. Luxembourg: Publications Office of the European Union; 2018 [displayed 22 March 2019]. Available at http://www.emcdda.europa.eu/ publications/adhoc/cannabis-legislation-europe en

15. United Nations Office on Drugs and Crime (UNODC). Single Convention on Narcotic Drugs, 1961 [displayed 22 March 2019]. Available at https://www.unodc.org/unodc/en/treaties/ single-convention.html

16. Danenberg E, Sorge L, Wieniawski W, Elliott S, Amato L, Scholten W. Modernizing methodology for the WHO assessment of substances for the international drug control conventions. Drug Alcohol Depend 2013;131:175-81. doi: 10.1016/j.drugalcdep.2013.02.032

17. United Nations Office on Drugs and Crime (UNODC). Convention on Psychotropic Substances, 1971 [displayed 22 March 2019]. Available at https://www.unodc.org/unodc/en/ treaties/psychotropics.html

18. United Nations Office on Drugs and Crime (UNODC). United Nations Convention against Illicit Traffic in Narcotic Drugs and Psychotropic Substances, 1988 [displayed 22 March 2019]. Available at https://www.unodc.org/unodc/en/treaties/ illicit-trafficking.html

19. Aizpurua-Olaizola O, Elezgarai I, Rico-Barrio I, Zarandona I, Etxebarria N, Usobiaga A. Targeting the endocannabinoid system: future therapeutic strategies. Drug Discovery Today 2017;22:105-10. doi: 10.1016/j.drudis.2016.08.005

20. National Academies of Sciences, Engineering, and Medicine. The health effects of cannabis and cannabinoids: the current state of evidence and recommendations for research Washington (DC): The National Academies Press; 2017. doi $10.17226 / 24625$
21. Directive 2001/83/EC of the European Parliament and of the Council of 6 November 2001 on the Community code relating to medicinal products for human use [displayed 22 March 2019]. Available at https://eur-lex.europa.eu/eli/dir/2001/83/ oj

22. European Medicines Agency. Orphan designation: Cannabidiol for: the treatment of Dravet syndrome [displayed 22 March 2019]. Available at https://www.ema.europa.eu/ en/medicines/human/orphan-designations/eu3141339

23. European Medicines Agency. Epidyolex. EPAR [displayed 22 March 2019]. Available at https://www.ema.europa.eu/ en/medicines/human/EPAR/epidyolex

24. Electronic Medicines Compendium (EMC). Sativex Oromucosal Spray. SmPC, 2018 [displayed 22 March 2019]. Available at https://www.medicines.org.uk/emc/product/602/ smpc

25. Danish Medicines Agency. Medicinal use of Cannabis, $3^{\text {rd }}$ ed. Copenhagen: Medicines Control \& Inspection; 2015. File no.2013113424/ [displayed 22 March 2019]. Available at https://laegemiddelstyrelsen.dk/en/news/2015/updatedmemo-on-medicinal-use-of-cannabis/ /media/ CA79D52432AC4045A999C6C183FB173B.ashx

26. Drugs.com. Cesamet [displayed 22 February 2020]. Available at https://www.drugs.com/cesamet.html

27. Álvares M. After legalisation, what next for medical cannabis in Portugal? Health Europa [displayed 30 January 2020]. Available at https://www.healtheuropa.eu/medical-cannabisin-portugal/90986/

28. Státní agentura pro konopí pro léčebné použití (SAKL). 236/2015 Coll. Decree of 4 September 2015 stipulating the conditions of prescribing, preparation, distribution, dispensing, and use of magistral formulas containing medical cannabis [cited 2019 May 5]. Available at http://www.sakl. cz/assets/user/Decree\%20No\%20236-2015.pdf

29. Federal Institute for Drugs and Medical Devices. Annual Report 2017/2018. Bonn: Federal Institute for Drugs and Medical Devices, 2018 [displayed 22 March 2019]. Available at https://www.bfarm.de/SharedDocs/Downloads/EN/ BfArM/Publikationen/AnnualReport2017-18.pdf? blob $=$ publicationFile $\& v=4$

30. Office of Medicinal Cannabis. Medicinal cannabis. The Hague: Institute for Responsible Medicine Use and the Office of Medicinal Cannabis of the CIBG, 2011 [displayed 22 March 2019]. Available at https://english.cannabisbureau.nl/ medicinal-cannabis

31. Regulation (EU) 2015/2283 of the European Parliament and of the Council of 25 November 2015 on novel foods, amending Regulation (EU) No 1169/2011 of the European Parliament and of the Council and repealing Regulation (EC) No 258/97 of the European Parliament and of the Council and Commission Regulation (EC) No 1852/2001 [displayed 22 March 2019]. Available at https://eur-lex.europa.eu/eli/ reg/2015/2283/oj

32. Deutscher Arzenimittel-Codex Neues Rezeptur-Formularium. Cannabis [displayed 22 February 2020]. Available at https:// dacnrf.pharmazeutische-zeitung.de/index.php?id=suchen

33. Zakon o lekarniški dejavnosti [Pharmacy Practice Act, in Slovenian]. Uradni list RS, št. 85/16 [displayed 22 February 2020]. Available at http://www.pisrs.si/Pis.web/ pregledPredpisa?id=ZAKO7375 
34. Čufar A. Regulatorni vidik predpisovanja kanabinoidov [Prescribing of cannabinoids - a regulatory view, in Slovenian]. Farm Vestn 2016;67:91-6.

35. World Health Organization (WHO). WHO guidelines on good agricultural and collection practices (GACP) for medicinal plants. Geneva: WHO; 2003 [displayed 22 March 2019]. Available at http://apps.who.int/medicinedocs/pdf/ s4928e/s4928e.pdf

36. European Medicines Agency. Guidelines on Good Agricultural and Collection Practices (GACP) for starting materials of herbal origin, $2006 \mathrm{Feb}$. EMEA/ HMPC/246816/2005 [displayed 22 March 2019]. Available at https://www.ema.europa.eu/en/documents/scientificguideline/guideline-good-agricultural-collection-practicegacp-starting-materials-herbal-origin_en.pdf

37. Malta Medicines Authority. General Guidelines on the Production of cannabis for medicinal and research purposes, 2018 Dec. Ref No: GL-CAN01/01 [displayed 22 March 2019]. Available at http://www.medicinesauthority.gov.mt

38. Manifava D. Greece grants country's first medical cannabis licenses, 2018 [displayed 22 March 2019]. Availble at http:/ www.ekathimerini.com/234842/article/ekathimerini/news/ greece-grants-countrys-first-medical-cannabis-licenses
39. Nanaimo B.C. Tilray ${ }^{\circledR}$ Increases International Export Capacity with New Outdoor Cultivation Site in Portugal, 2019 [displayed 22 March 2019]. Available at https://www. tilray.com/tilraynews-master/2019/8/7/tilray-increasesinternational-export-capacity-with-new-outdoor-cultivationsite-in-portugal

40. Agency for Medicinal Products and Medical Devices of the Republic of Slovenia. Andreja Čufar. Stališče JAZMP v zvezi s predlogom o spremembi razvrstitve konoplje in ureditvi gojenja konoplje [JAZMP's position on the proposal to amend the classification of cannabis and the regulation of cannabis cultivation, in Slovenian] [displayed 30 January 2020]. Available at https://www.jazmp.si/fileadmin/datoteke/ dokumenti/Stalisce_JAZMP_glede_konoplje.pdf

41. Publications Office of the EU. C/2017/4132 Common catalogue of varieties of agricultural plant species - fifth supplement to the $35^{\text {th }}$ complete edition. Avilable at: https:// op.europa.eu/en/publication-detail/-/publication/3d31e8185715-11e7-a5ca-01aa75ed71a1

42. European Commission. EU Novel food catalogue. Available at: http://ec.europa.eu/food/safety/novel_food/catalogue/ search/public/?event $=$ home\&seqfce $=72 \&$ ascii $=$

\section{Kanabis in kanabinoidi v medicini - zakonodajni vidik}

Odkritje endokanabinoidnega sistema je vzbudilo zanimanje javnosti za medicinsko uporabo konoplje, fitokanabinoidov in sintetičnih kanabinoidov, ki je bila zaradi psihotropnih učinkov in morebitne zlorabe že od nekdaj natančno regulirana. $\mathrm{V}$ prispevku je predstavljen pravni okvir Evropske unije, ki ureja uporabo in gojenje konoplje v medicinske namene, $\mathrm{v}$ skladu s konvencijami Združenih narodov o proizvodnji, trgovini in uporabi konoplje, fitokanabinoidov in sintetičnih kanabinoidov. Medtem ko zakonodaja Evropske unije natančno določa zahteve in postopke izdaje dovoljenja za promet za avtorizirana zdravila, ni skupnega regulatornega okvira za magistralne in oficinalne pripravke, ki so izvzeti iz avtorizacijskih postopkov. Njihova ureditev je prepuščena vsaki državi članici in se zaradi tega razlikuje, predvsem zaradi kulturnih in zgodovinskih razlik med državami, to pa vodi do različne dostopnosti do tovrstnih zdravil. Zaradi tega bi bili dobrodošli nekateri usklajeni pristopi držav članic EU, s katerimi bi zmanjšali razlike na trgu neavtoriziranih zdravil s kanabinoidi.

KLJUČNE BESEDE: kanabis; endokanabinoidi; sintezni kanbinoidi; medicinska uporaba; gojenje konoplje; zakonodaja 